REFUGEES OF THE FRENCH REVOLUTION 
This page intentionally left blank 


\section{Refugees of the}

\section{French Revolution}

Émigrés in London, 1789-1802

Kirsty Carpenter

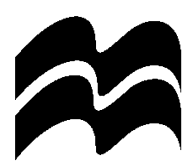


First published in Great Britain 1999 by

\section{MACMILLAN PRESS LTD}

Houndmills, Basingstoke, Hampshire RG21 6XS and London

Companies and representatives throughout the world

A catalogue record for this book is available from the British Library.

ISBN 978-1-349-40391-2 ISBN 978-0-230-50164-5 (eBook)

DOI 10.1057/9780230501645

First published in the United States of America 1999 by

ST. MARTIN'S PRESS, INC.,

Scholarly and Reference Division,

175 Fifth Avenue, New York, N.Y. 10010

ISBN 978-0-312-22170-6

Library of Congress Cataloging-in-Publication Data

Carpenter, Kirsty, 1962-

Refugees of the French Revolution : émigrés in London, 1789-1802 /

Kirsty Carpenter.

p. $\mathrm{cm}$.

Includes bibliographical references (p. ) and index.

ISBN 978-0-312-22170-6

1. French-England-London-History-18th century. 2. France-

-History-Revolution, 1789-1799-Refugees. 3. French-England-

-London-History-19th century. 4. Political refugees-England-

-London-History. I. Title.

DA676.9.F74C37 1999

$942^{\prime} .00441-\mathrm{dc} 21$

99-13682

CIP

\section{(C) Kirsty Carpenter 1999}

Softcover reprint of the hardcover 1st edition 1999 978-0-333-71833-9

All rights reserved. No reproduction, copy or transmission of this publication may be made without written permission.

No paragraph of this publication may be reproduced, copied or transmitted save with written permission or in accordance with the provisions of the Copyright, Designs and Patents Act 1988, or under the terms of any licence permitting limited copying issued by the Copyright Licensing Agency, 90 Tottenham Court Road, London W1P 0LP.

Any person who does any unauthorised act in relation to this publication may be liable to criminal prosecution and civil claims for damages.

The author has asserted her right to be identified as the author of this work in accordance with the Copyright, Designs and Patents Act 1988.

This book is printed on paper suitable for recycling and made from fully managed and sustained forest sources.

$\begin{array}{llllllllll}10 & 9 & 8 & 7 & 6 & 5 & 4 & 3 & 2 & 1\end{array}$

$\begin{array}{llllllllll}08 & 07 & 06 & 05 & 04 & 03 & 02 & 01 & 00 & 99\end{array}$ 
à mon mari 
This page intentionally left blank 


\section{Contents}

Lists of Figures and Tables

viii

List of Illustrations

ix

Acknowledgements

xiii

Introduction

xiv

1 First Impressions

2 1789-92: a Prolonged Vacation

3 1792: the Influx

4 Soho

5 Marylebone, Richmond, Hampstead - the High Life

6 St Pancras, Somerstown, Saint George's Fields the Low Life

7 Educational Pursuits

8 Politics: Their Own Worst Enemies?

9 Émigré Writers and Writing about Émigrés

10 Franco-British Culture and Society

Conclusion

Appendix 1: Chronology

Appendix 2: Figures and Tables

Notes

Bibliography

Index 


\section{Lists of Figures and Tables}

Figures in Appendix 2

1. Towns listed as lay émigré centres in the British Relief Lists

2. Lay émigrés receiving relief from the British government, 1794-97

3. Place of origin given by the refugees in London

4. Money-flow into the voluntary relief fund in its first year

5. Date of emigration from France

6. Émigrés in and outside London in $\mathbf{1 7 9 7}$

7. Refugee addresses in London

8. British subscribers to the voluntary relief fund

9. Servants receiving relief, 1794-97

10. Gender analysis of servants receiving relief after 1796

11. Lay émigrés receiving relief in 1797

12. Lay émigrés receiving relief in 1799

13. All émigrés receiving relief in October 1801

14. All émigrés receiving relief in March 1802

\section{Tables}

$4.1 \quad$ Illnesses among émigrés, $1796 \quad 59$

A.1 Statistical analysis of lay émigrés receiving relief, 1794-97 205 


\section{List of Illustrations}

1. A French Family by Thomas Rowlandson, 1792 (British Library, Prints and Drawings No. 9686, published by Fores, Piccadilly in 1792) (C) British Museum xxvi

2. Salus in fuga: La France se purge petit à petit by George Cruickshank (BL Prints and Drawings No. 7663, 29 July 1790) (C) British Museum

xxvii

3. Map of London and Westminster, John Fairburn, 1796 (C) British Library (Maps C 27. b. 73)

xxviii 
This page intentionally left blank 
L'exil est quelquefois, pour les caractères vifs et sensibles, un supplice beaucoup plus cruel que la mort.

Mme de Staël, Corinne 
This page intentionally left blank 


\section{Acknowledgements}

There have been many people whose help, patience and wise counsel have contributed to this book. It is based on a thesis directed by Michel Vovelle (Paris I, 1993) and, for me like many, his great example as a researcher has been an inspiration. I have many French friends whose enthusiasm, support for my work and generous hospitality have made the experience of writing a thesis then a book so very enjoyable. I would particularly like to mention the Rolland family in Angers who were wonderfully supportive in the first year of my time in France and the Domenech family who are very dear to me, especially Claire and Didier Marillet. The tolerant scrutineers who gave invaluable comments on the manuscript include Maurice Hutt, Philip Mansel, and Dominic Bellenger. I would also particularly like to thank Pamela Pilbeam and the members of the Modern French History Research Seminar at the Institute of Historical Research and the Institut Français for their support and constructive criticism.

I have had help and support from the staff of many institutions: the British Library, the Public Records Office, the Bibliothèque Nationale, the Archives Nationales, the Ministère des Affaires Etrangères, and from my university colleagues in France, the UK and now New Zealand where I have taught since 1994. Special thanks must go to a dear friend and mentor, Robert Neale, who edited the manuscript with meticulous care.

To all these people I am extremely indebted and profoundly grateful but none more so than to Andrew who has lived with the French Revolution and émigrés for many years now and shared the happy times and the heartaches with tolerance and love. 


\section{Introduction}

Since the time of the Revolution the Emigration has received a very bad press. The émigrés have been accused of many crimes in the intervening years, against humanity (which the Revolution claimed to defend), against the French people and against the French state. Yet what was their crime? We find the most comprehensive reply in the mouth of one of Balzac's characters:

Quitter la France est, pour un Français, une situation funèbre.

For a Frenchman, leaving France is a sorry business. ${ }^{1}$

The fact that they left the country, isolated themselves from political developments and alienated themselves from individuals with similar political sympathies inside France, was an important factor. When communications broke down and emigration was made punishable by death, this indeed became a 'situation funèbre'.

The émigrés have been refused a place in the history of the French Revolution and refused a voice in the crowd because they deserted their country and some took arms against it. By revolutionary legislation they were stripped of their rights as French citizens and condemned to death if caught on French soil. These laws left little possibility for them to make their case before their fellow-citizens.

Popular images of emigration, like Salus in fuga, portray the émigrés as deluded aristocrats who left France in dribs and drabs hastening to the frontier to join the forces being raised by the princes near Coblenz or slipping across the British channel under the cover of darkness in stormy seas. They took the only option left to them, their political views surpassed and defeated by the euphoria of the National Assembly in its glory days.

These are myths, powerful myths it is true, which, throughout the nineteenth century, Republican tradition has had no interest in toppling. Many Frenchmen thought that the émigrés received their compensation in the Indemnity Bill of 1825 - much too much, in the eyes of many nineteenth-century liberals.

In French political tradition the émigrés have become inextricably linked with a movement of staunch inflexibility which characterised the ultra-royalist or 'ultra' faction at the time of the Revolution. 
Ex-émigrés who dominated politics during the Restoration saw to it that the emigration was entirely associated with support for the Bourbon cause. Constitutionnels or those who supported a compromise between absolute monarchy and republic were objects of ridicule from both sides for reasons treated fully in Chapter 8 .

In Britain, the destination of many émigrés, the scene was set for the ideas of Revolution to come into conflict with reason and the good sense of the Glorious Revolution, particularly in regard to issues of taxation and equity before the law. Moreover, the British response was important. Britain did not join the war against France until February 1793 and it did not want to be involved in a European war with the economic wounds of the recent colonial conflict still painful. The British reception of the refugees was therefore somewhat involuntary but prompted by a sense of duty, honour and obligation to support those whose position was in sympathy with their own.

The diplomatic history of the eighteenth century had been a series of defeats for France inflicted primarily by Britain. ${ }^{2}$ In 1789 France was still smarting from the humiliation of the Seven Years War but, at great expense, it had won the latest round when the American colonies gained their independence from the British throne and a parliament in which they had never been represented.

For the British it was national pastime to to dislike the French. They were a shady lot who lived on onions and could not be trusted.

\begin{abstract}
'Ah,' says one man to his companion, 'one had need to go to France to know how to like old England when one gets back again.' 'For my part,' rejoined another, 'I've never been able to get drunk once the whole time I was in France - not a drop of porter to be had - and as for their victuals, they call a bit of meat of a pound and a half, a fine piece of roast beef.'3
\end{abstract}

Politically, relations between the two states were tense and suspicious. Culturally, they were as cordial as ever with the British consuming just as much French wine, coveting the latest French fashions and reading as much French literature.

My liking for Mme de Sévigné is, I suppose, owing to my very ignoble love of gossip, which, if it be but honest and natural, I always like, whether on paper or de vive voix. And French, being the very language of chit-chat and prittle-prattle, is one reason why I like so much the mémoires and letters of that gossiping nation. ${ }^{4}$ 
By the end of the eighteenth century, French was the time-honoured language of chit-chat and prittle-prattle on the social and political scene. Prominent members of both communities engaged in lengthy discourse par écrit; Horace Walpole and Madame du Deffand are an extreme case but many others were in regular contact like Jules de Polignac and the Duke of Devonshire. ${ }^{5}$ It was in the best of taste to cultivate things French not only in London but also in the provinces. ${ }^{6}$

Ah! les Anglais, les Anglais ont bien des singularités! ${ }^{7}$

Ah! The English, the English have many peculiarities!

Yet by 1793 attitudes towards the British inside revolutionary France were far from neutral. The British, and the émigrés with them, were held responsible by the revolutionaries for all the problems which France was facing. In Paris Barère and other prominent Jacobins were advocating national hatred for the British as an integral part of French republicanism. ${ }^{8}$ Barère was among those who incited the French to believe that, without the British, Europe would be free from its shackles.

que les esclaves anglais périssent et l'Europe sera libre. ${ }^{9}$

At a time when political propaganda was discovering its potential among a rapidly expanding readership, information, or lack of it, was central: central to the effectiveness of revolutionary propaganda and central to the case made against the Revolution by the émigrés. By portraying them as one group, united by the political aim of destroying the Revolution and restoring the absolute monarchy, the revolutionary government controlled opinion. Censorship legislation saw to it that the royalist press had no outlet in the capital and therefore had no access to the public. From 10 August 1792 until the death of Robespierre, the royalist press inside France was silenced. On 29 March 1793 the death penalty was voted in for anyone seeking the reestablishment of the monarchy. Many political journalists were victims of the guillotine, like the two poets Roucher and André Chénier, who died two days before Robespierre condemned 'writers hired by the tyrant to mislead and corrupt public opinion'. ${ }^{10}$ The Law of Suspects (17 September 1793) left writers with royalist sympathies few options: they emigrated, they transferred their talents to the Republic or they disappeared in the provinces in order to avoid arrest and certain death. 
Royalist newspapers did re-emerge cautiously during the Thermidorean period because the revolutionary laws were not policed with the same vigour, and this continued during the First Directory. However, the Fructidor coup of September 1797 put an end to any leniency and during 1798 and 1799 journalists, editors and owners of newspapers were deported in significant numbers. ${ }^{11}$ Effectively by the time Napoleon came to power in December 1799 the royalist press in France had virtually ceased to exist. Then, during the Empire, wellpoliced censorship completely eradicated the royalist voice inside France and left the field clear for the émigré press based in London. ${ }^{12}$

Therefore, in a revolution where political communication was, more than ever before, central to the spread of ideas and the popularity of revolutionary propaganda, it is very important that punitive laws suppressed the voice of those who challenged revolutionary government. Many émigrés were the authors of reasoned polemics like the early political writings of André Chénier advocating nothing more, initially, than moderate constitutional monarchy. Yet André Chénier, who paid for his reason with his head, like many émigrés, underwent a political evolution from reasoned moderation to fanatical anti-Jacobinism. Chateaubriand is a parallel example who underwent a similar transition from moderate constitutional monarchist to ultra-royalist between his two works The Historical Essay on Ancient and Modern Revolutions (1797) and the Genius of Christianity (1802). ${ }^{13}$

Polarisation in the case of individual opinions was a characteristic of the emigration, just as it was a characteristic of the Revolution. No individuals returned from exile unchanged. All émigrés endured long periods of relative inactivity due to a host of constraints, geographic, financial, political and social, which left them nothing else but their political positions to re-examine. This alone was a new experience for many used to constant society and a very different lifestyle. Many of the émigrés describe the soul-searching which went on day after day among both women and men trying to come to terms with the Revolution and the options which remained open to them.

It is imperative to underline the fact that there was no one political philosophy represented in emigration but that there were a number of political positions which co-habited, sometimes uncomfortably, outside France. A dominant faction has been identified in retrospect, and in the knowledge of the Restoration but, at the time when a Restoration was far from certain, the politics of emigration were as diverse and unpredictable as the politics of the Constituent Assembly. Studies which have detailed the shifts in voting patterns during the 
two initial phases of the Revolution, the Constituent Assembly (1789-91) and the Legislative Assembly (1791-92) emphasise the haphazard nature of votes and the unpredictability of the outcomes due to the multitude of political views and the assertion of individuality on the part of the deputies. ${ }^{14}$ Many of the émigrés of late 1791 to 1792 shared the diverse visions and the social background of the members of the Constituent Assembly, which make these studies illustrative of a broader phenomenon: that of the diversity of political opinions in general in France before the radical phase of the Revolution which began on 10 August 1792, and the lack of any model for political behaviour. This diversity, or lack of agreement in regard to political solutions, was responsible for many defections into emigration.

There are many correspondences too between émigrés and Frenchmen who did not leave France. The period directly after the fall of Robespierre is particularly illustrative of the similarities between the moderate elements of both sides. The members of the government which had survived the Terror and shed the radical Jacobin deputies (i.e. Robespierre, Saint Just, etc.) were preoccupied with the preservation of the Revolution and the Republic while ensuring that the Terror could not legally be reinstated and that the monarchy could not be restored. Throughout this period, moderate Republicans and moderate Royalists are almost indistinguishable in their political desires and objectives except on the question of head of state, and even this is ambiguous.

What that illustrates is the lack of any clean-cut divisions between a significant proportion of émigrés and the vast majority of republicans. By the late 1790s France was manifesting the essential characteristics of French politics in the nineteenth century. Even in regard to 1830, tales of an old aristocratic monarchist France at war with a new bourgeois country are dismissed as ultra-royalist anachronisms.

While the vast majority preferred to maintain a constitutional monarchy because they knew they could not agree amongst themselves on an alternative and were fearful of popular upheaval, their monarchism was entirely pragmatic. ${ }^{15}$

This is primarily the reason that royalists in France accepted the Constitution of Year III $^{16}$ because, although a monarchy could not legally be restored during the life of that Constitution, it provided the effective basis of a constitutional monarchy with five Directors sharing the responsibilities of a King. It is significant that this Constitution 
contained clauses which reaffirmed the position of the French state in regard to émigrés. Under no circumstances were they to be allowed to return and the Constitution prohibited the Legislature to make new exceptions to existing émigré legislation. It also reaffirmed that émigré property was the property of the Republic and that purchasers of this property, providing that they had acquired it through the legal channels, could not be dispossessed. ${ }^{17}$ Yet, significantly, nowhere in the Year III Constitution was a definition of the term 'émigré' attempted.

Political pragmatism perpetrated by a property-owning liberal elite was therefore beginning to assert itself as early as 1795 when the stranglehold represented by the Maximum on the economy was lifted (December 1794) and the Constitution of Year III simultaneously institutionalised the commitment of the government to 1792 and the rejection of the Terror. ${ }^{18}$ The resultant weakness and instability of the Directory governments were not a product of the Constitution per se but, rather, a product of the political situation in which it was introduced. It was written not for a wartime economy but for a peacetime environment and that quickly became apparent.

The turning-points for departure from France are the Great Fear (July 1789), Varennes (June 1791), from 10 August 1792 to the September Massacres, and the 1793 legislation. This was passed on 28 March-5 April and tidied up all the loose ends in relation to émigrés and enemies of the state. The 1793 legislation which made emigration punishable by death and decreed all émigrés forfeit of their French citizenship, is treated more fully in Chapter 3.

The turning-points for returns are less numerous. The first opportunity came at the end of 1791 when an amnesty period of two months was declared in order to allow émigrés to return or face prosecution for conspiracy..$^{19}$ This decree of 9 November 1791 was vetoed by the King and could not be put into effect yet, in practice, the amnesty applied. On 8 April 1792 another law declared the property of all émigrés absent since 1 July 1789 forfeit to the state if they had not returned within a month. The King consistently vetoed legislation relating to émigrés and refractory priests until his deposition in August 1792.20 Once the Convention met in September 1792 the position on the émigrés became law. On 23 October they were banished in perpetuity from French soil and those caught on French soil were condemned to death. A short amnesty (of 15 days) was accorded to allow those who wished to re-enter the country to do so. The next opportunity to return after the passing of the 1793 legislation did not come until after the death of Robespierre and the end of the Terror. The laws against 
émigrés were still in force and émigrés were still inscribed on the police lists but there were few deaths during the Thermidor period and only the most extreme cases were deported. This had more to do with a revulsion for blood shed in the aftermath of the Terror than any revision of policy on émigrés. ${ }^{21}$ Under the First Directory, which came into existence in October 1795 with the completion of the Constitution of Year III and subsequent elections, moderate royalists within France began to re-establish their influence in the Assembly, which had changed its name from the Convention (too closely associated with the Terror) to the Council of Five Hundred. Fears of election victories for deputies with either royalist or radical Jacobin sympathies led to the contravention of this Constitution before it was even implemented. The parting gesture of the old Convention was to pass the Decree of Two Thirds on the same day that it accepted the Constitution (22 August 1795) which ruled that two-thirds of the existing deputies had to be re-elected to the new legislature and thereby ensured republican dominance.

This provoked the uprising of 13 Vendémiaire which became a milestone in the French Revolution because, for the first time since 1792, the Paris mob did not get what they wanted from government by threatening lack of support and in turn found themselves brutally repressed. This revolt was supported by many different strains of counter-revolutionaries who did not want to see the former members of the Convention retain their seats and, in its wake, several deputies with known royalist sympathies were arrested. The law of 3 Brumaire an IV (25 October 1795) was the legal reaction to the Vendémiaire uprising. It prohibited from holding elective public office any member of the primary or electoral assemblies who had been in any way associated with protest against the Law of Two Thirds and it also excluded from public office anyone who had been listed as an émigré without obtaining full radiation or any relative of a listed émigré. Women related to émigrés were required by the same law to return to their domicile of 1792 and remain under the surveillance of the municipal authorities and the laws against priests, which had effectively been suspended, were reimposed with a vengeance.

The passage of the 3 Brumaire law ensured that issues regarding émigrés and their relatives, bien nationaux and refractory priests were high on the agenda of the First Directory. There were many inconsistencies in the sale of bien nationaux and many sales and potential sales were being contested. Catholic issues too were of central importance for a variety of political and private reasons. What this highlights is 
that the political ramifications of any repeal of the émigré laws rendered revision impossible. The cost of investigating the issues which would have had to be faced were any revision to take place was far too high for any fragile Directory Government to give it serious consideration. But the issue here was larger and more dangerous than it appears at first reading. It was not the émigrés but the legality of the regime which had condemned them that was in question and therefore throughout the Directory any suggestion of injustice towards émigrés directly implicated the foundations of the Republic itself. While the Republic remained at war with Europe, the émigré question could not be resolved.

The course of 1796 was crucial for the royalist cause in France. The strong anti-Jacobin reaction which produced the White Terror in the provinces gave the moderate royalists some room to manoeuvre. This was a particularly important year for the destiny of the Revolution and a point at which it threatened to change course. It is also one of the best illustrations of the lack of coherence and trust between the royalists within France and the royalists without. Many royalists inside France felt that cooperation with the émigrés undermined their support and their constitutional position. Furthermore, Louis XVIII in the Declaration of Verona had alluded to a backlash against constitutional royalists should an absolute monarchy be re-established. This left a great many people with royalist sympathies stranded. They were bound to monarchy by their tradition and culture but the monarch Louis XVIII refused to consider a constitution, which left them looking for a monarch who would. ${ }^{22}$

It was this group of royalists who were in a strong position going into the elections of Year V (1797). They drew support from their moderation and the fact that their constitutional royalism linked them to the period of the Revolution which had preceded the radical events of the Terror. This royalism also appealed to many provincials for whom the more radical aspects of Revolution, and in particular the dechristianisation, made little sense. This, allied to the re-emergence of a radical Jacobin political element in French society, all contributed to the disadvantage of the republicans, many of whom were still former regicides, and to the favour of the moderate royalists.

Many émigrés returned in the period directly preceding the elections of 1797 in anticipation of a royalist victory and the imminent relaxation of the émigré laws. Many were waiting, not only for a relaxation of the laws which put them under threat of death, but also of the laws which deprived them of their properties and their children of 
their inheritance. There was even question of letting returned émigrés vote and in fact those who had managed to obtain provisional radiation in the provinces were allowed to do so, which showed how much ground had been gained by the royalists. The events surrounding the Year $\mathrm{V}$ elections were complicated by a host of issues related to the provincial administration and the waning of popular support for the Directory but the outcome was a resounding victory for the royalists and the prospect of an imminent relaxation of the émigré laws.

Between April and September 1797 (Floréal and Fructidor Year V), some major changes were made to the situation of the émigrés. On 27 April Boissy d'Anglas gave a speech in the Council of Five Hundred where he referred to the 'barbarous justice' by which the émigrés could be condemned to death on the strength of a simple identification if caught on French soil, and pleaded for trial in the ordinary courts. On 4 May the law of 3 Brumaire was amended to allow relatives of émigrés to hold office and on 27 June it was withdrawn altogether. There were other events in this period which indicated the strength of the royalist faction such as the election of Pichegru to the office of President of the Council of Five Hundred and the election of Barthélemy as a Director. It was also at this same time that polemics like Lally Tolendal's 'Defence of the Émigrés' appeared in print in exile.

The election result reached through legal channels left the executive of the Republic only one option: an unconstitutional one. In September 1797, therefore, the Fructidor coup purged the Assembly of the newly elected royalists and appointed candidates of known republican pedigree to the vacant seats or left them unfilled. The fact that a two-week amnesty was again declared before the émigré laws were reinforced to the letter suggests just how many émigrés had attempted to return. The government also introduced an oath of hatred to royalty which all ecclesiastics had to take.

The outcome was known as the Directorial Terror. The revolutionary regime's first action was to reinstate the law of 3 Brumaire and it quickly rendered the émigré position that which it had been in 1792-93. Unlike the Terror of 1794 the Directorial Terror shed little blood and used instead the 'guillotine sèche' or deportation to Guiana as its method of execution but it did establish the law of 9 Frimaire an VI (29 November 1797) whereby ex-nobles were excluded from public office and regarded as foreigners if they could not prove that they had served the Revolution. This law was the subject of much debate in 1798 because no test for proving service to the Revolution was 
included in the legislation. In practice it was implemented very sparingly because it threatened people in very high places like Barras and Bonaparte.

The events of Year VI offered little hope of change to the émigré situation. The war, the economy and the renaissance of Catholicism in France all contributed to keep government policy rigid. Elections were always contentious: those of Year VI produced the Foréal Coup, which purged the Assembly of legally elected radical Jacobin deputies in order to prevent a shift to the far left, and those of Year VII, preceding the Brumaire coup by a few months, were characterised by an even more unsatisfactory result. The government, known as the Second Directory once it had contravened the Constitution of Year III, had to go on doing so. The deterioration of the economy and the desperate need of conscripts for the army resulted in the Law of Hostages (24 Messidor an VII, 12 July 1799) which outlawed any resistance to new measures. By this law local authorities were empowered to arrest relatives of émigrés, imprison them at their own expense and impound their property to pay for damages. It was a new Law of Suspects with wider and more frightening consequences than that of 1793 for families of émigrés resident in France.

Effectively after the Fructidor coup the next return opportunity for the émigrés did not come until the Peace of Amiens was signed on 25 March 1802. From the arrival of Bonaparte as First Consul the signs of a pending reconciliation between the royalists and the Jacobins emerged. In November 1799 the Law of Hostages was repealed and the government also lifted the legal penalties on the relatives of émigrés and commuted the oath of hatred to royalty to one of loyalty to the Constitution. Relatives of émigrés and nobles were restored to full voting citizenship and the Revolution was declared to be at an end (15 December 1799).

On 3 March 1800 a further decree closed the émigré list and a commission was appointed to speed up the radiation process. Although émigrés began to return, encouraged by the positive signs, it was still dangerous. However, after Bonaparte's dazzling victory at Marengo, Pope Pius VII, despite the views of the émigré bishops in Britain, was persuaded of the desirability of reconciliation and the Concordat, signed on 15 July 1801, achieved it. Catholicism was named the religion of the majority of Frenchmen.

This was the point at which the vast majority of émigrés, including the ecclesiastics, returned to France. Those who remained in exile after 1802 were those who refused to give up plotting to 
restore the monarchy. It is this 'noyau dur' of emigration whose social make-up and political actions have been attributed to the entire émigré population.

It is therefore the legislation which provides the clue to the real level of émigré commitment to the Bourbon cause. The revolutionary legislation reveals how few alternatives the émigrés had after 1792 and that same legislation holds the clue to the multitude of related issues which prevented any revision of the émigré laws before 1802 .

The fact that the last returns of 1814 represented the smallest number of émigrés (with far greater numbers returning in 1802) certainly suggests that the link between the émigrés and the Bourbon monarchy was more tenuous than it has been portrayed both by Revolutionary and Counter-Revolutionary historians. ${ }^{23}$ Moreover the fact that the Charter, which was the basis of Louis XVIII's restored government, represented a concession to moderate constitutional monarchy illustrates not only the pragmatism of the architects of the Restoration but the minimum requirement of the French nation in the wake of Revolution and Empire in order to avoid civil war.

In 1814 Europe was exhausted and peace was the overriding objective. For many it would not become clear until after the failure of the Second Republic and the creation of the Empire in 1851 that the French wanted strong government worthy of historical precedents like François I, Henry IV, Louis XIV and Napoleon but, at the same time, worthy of the collective intellectual tradition of the Enlightenment and the Revolution. One hundred years after the Revolution they achieved it in the Third Republic, the longest, most stable and most internally contradictory regime France has ever known.

This study of the émigré population in London will I hope bring out some of the diversity present in the exile community and overturn the notion that the émigrés represented one united voice. I have particularly focused on the social intercourse between the émigrés and the British during the 1790 s which, while it develops these themes, also explores the antecedents of the complex love-hate relationship which characterises the two nations to this day.

Like Zeldin, I believe that historical study is a personal experience. ${ }^{24}$ My own fascination for the Revolution years comes from my love of eighteenth- and nineteenth-century French literature. I have 
always found myself especially drawn to literature which does not fit neatly into any established category: the political pamphlets, the memoirs and the poetry which was written not to dazzle the reader with its literary quality but to contribute to a political debate. It is from this literature that many of the quotes in this book are chosen. They are passages which would otherwise be ignored or discarded but, in their own social and historical context, are often humorous and enlightening.

K. CARPENTER 
xxvi

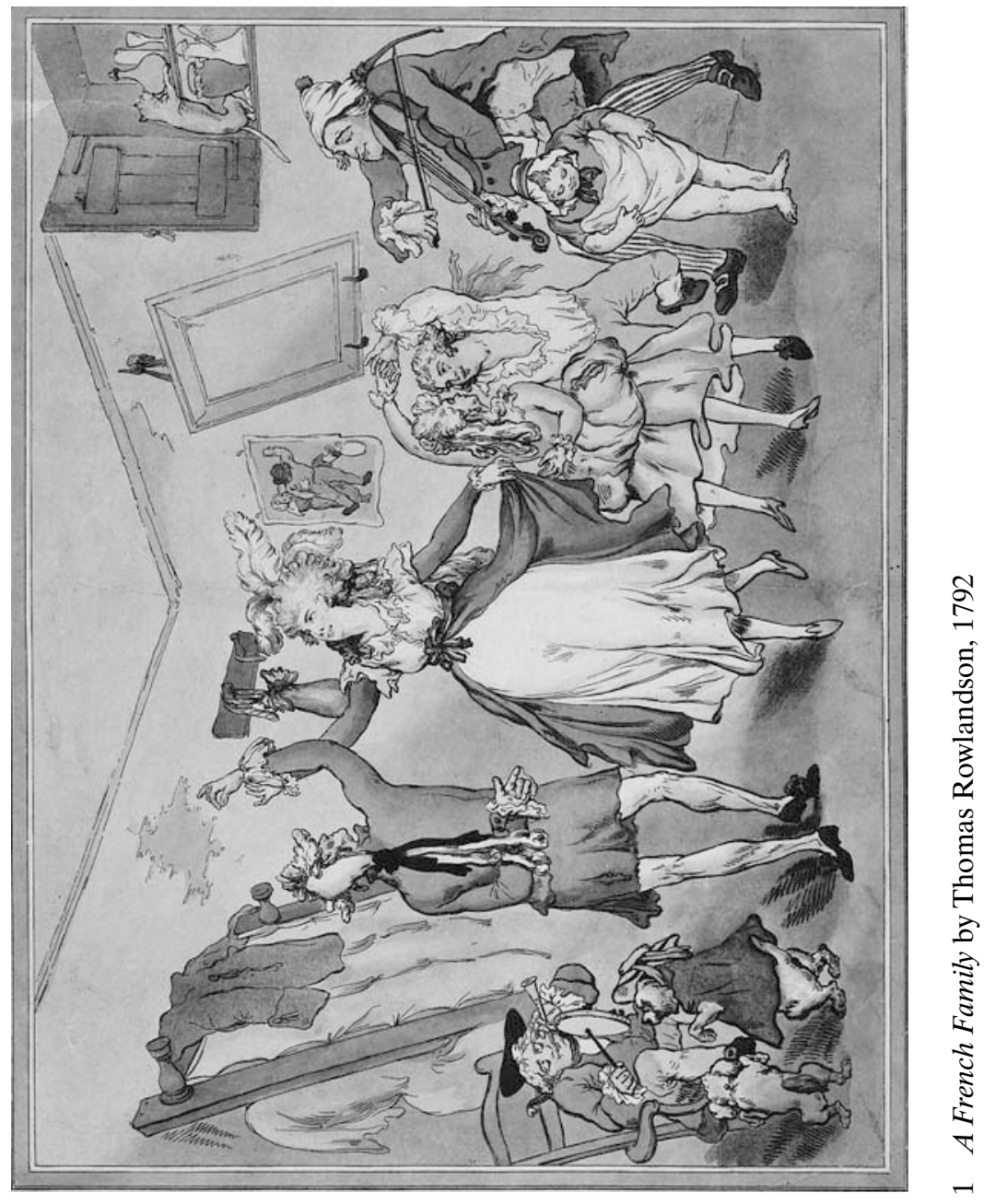


xxvii

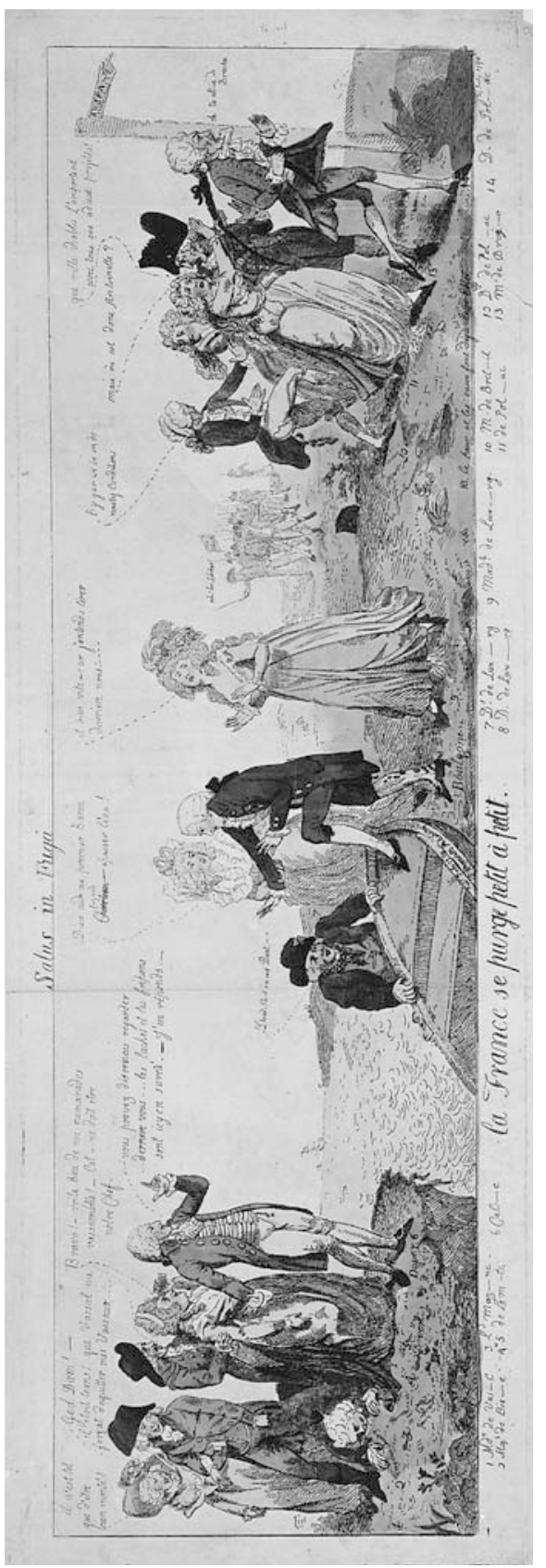

o 


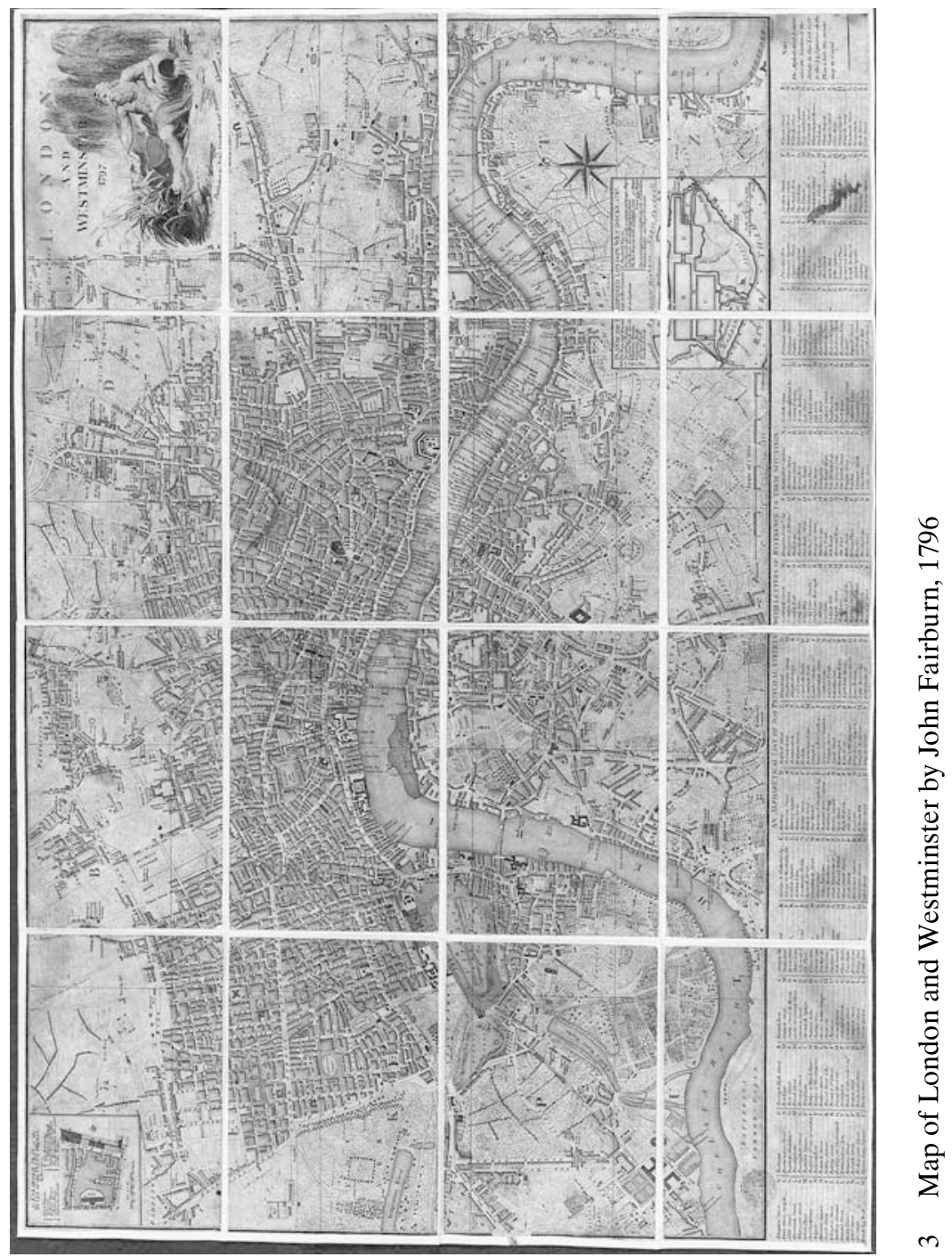

